\title{
An analysis of the spatiotemporal distribution of American cutaneous leishmaniasis in counties located along road and railway corridors in the State of Maranhão, Brazil
}

\author{
Vicente Silva Gonçalves Neto[1],[2], Allan Kardec Duailibe Barros Filho ${ }^{[1],[3],}$ \\ Alcione Miranda dos Santos ${ }^{[4]}$, Margarida Paula Carreira de Sá Prazeres ${ }^{[5]}$, \\ Ana Célia Rolim Bezerril ${ }^{[6]}$, Alexandre Vitor de Lima Fonseca ${ }^{[7]}$ \\ and José Manuel Macário Rebêlo[8],[9]
}

[1]. Rede Nordeste de Biotecnologia. [2]. Coordenação de VISA de Portos, Aeroportos e Fronteiras, Agência Nacional de Vigilância Sanitária, São Luis, MA. [3]. Laboratório de Processamento da Informação Biológica, Departamento de Engenharia Elétrica, Universidade Federal do Maranhão, São Luis, MA. [4]. Programa de Pós-Graduação em Saúde Coletiva, Departamento de Saúde Pública, Universidade Federal do Maranhão, São Luis, MA. [5]. Agência Estadual de Defesa Agropecuária, Secretaria de Agricultura, Pecuária e Pesca do Estado do Maranhão, São Luis, MA. [6]. Departamento de Epidemiologia, Secretaria de Saúde do Estado do Maranhão, São Luis, MA. [7]. Departamento de Geociências, Universidade Federal do Maranhão, São Luis, MA. [8]. Departamento de Biologia, Universidade Federal do Maranhão, São Luis, MA. [9]. Laboratório de Entomologia e Vetores, Departamento de Patologia, Universidade Federal do Maranhão, São Luis, MA.

\begin{abstract}
Introduction: The incidence of American cutaneous leishmaniasis (ACL) is increasing in Latin America, especially in Brazil, where 256,587 cases were confirmed in the last decade. Methods: This study used a Bayesian model to examine the spatial and temporal distribution of ACL cases between 2000 and 2009 in 61 counties of State of Maranhão located along the three main road and railway corridors. Results: During the study period, 13,818 cases of ACL were recorded. There was a significant decrease in the incidence of ACL in the ten study years. The recorded incidence rate ranged from 7.36 to 241.45 per 100,000 inhabitants. The relative risk increased in $77 \%$ of the counties, decreased in $18 \%$ and was maintained in only five counties. Conclusions: Although there was a decreased incidence of the disease, ACL was present in all of the examined municipalities, thus maintaining the risk of contracting this illness.
\end{abstract}

Keywords: American cutaneous leishmaniasis. Bayesian model. Spatio temporal distribution. Relative risk.

\section{INTRODUCTION}

American cutaneous leishmaniasis (ACL) is an infectious disease affecting the skin and mucosa. It is caused by protozoa of the genus Leishmania and is transmitted by different species of phlebotomine sandflies ${ }^{1}$.

The incidence of ACL is increasing in Latin America, especially in Brazil, where 256,587 cases were recorded from 2000 to 2009 . In this period, $82,510(32.2 \%)$ cases were reported in the northeastern region of the country, of which 32,548 (39.4\%) came from the State of Maranhão

The State of Maranhão is located among three biomes that display variations in physiographic, climatic and ecosystem diversity. These regions are of critical importance in the

Address to: Dr. José Manuel Macário Rebêlo. Laboratório de Entomologia e Vetores/Depto de Patologia/UFMA. Praça Madre Deus 2, 65025-560 São Luis, MA, Brasil.

Phone: 5598 3231-3644

e-mail: vicgonster@gmail.com

Received 22 November 2012

Accepted 03 June 2013 epidemiology of ACL, as they are highly endemic for the disease. The Cerrados of central Brazil are situated in the eastern portion of this region, while Caatinga ecosystems are found to the northeast and the Amazonian forest to the west ${ }^{3}$.

Several researchers have conducted spatial analyses of the dynamics of infectious diseases ${ }^{4,5}$. The analysis of relative risk (RR) over space and time has received a great deal of attention in epidemiological studies over the last few decades. Many studies assume that RR is composed of several random components, and these components explain different variations related to risk, such as temporal and spatial effects ${ }^{4,6,7}$.

In this study, data on ACL from 2000-2009 were analyzed. The ACL data were expected to be correlated in space due to exposure to common environmental characteristics that influence transmission similarly in neighboring areas. The standard statistical methods assume independent observations. To take spatial correlations into account, Bayesian spatiotemporal models ${ }^{8,9}$ were developed to evaluate the spatiotemporal autocorrelation of the disease. Due to the large number of model parameters, a Markov Chain Monte Carlo (MCMC) simulation was used for model fitting.

This study aimed to assess the spatiotemporal distribution of ACL in counties located along road and railway corridors in the State of Maranhão, Brazil. 


\section{METHODS}

We conducted a retrospective ecological study describing the spatiotemporal distribution of ACL cases in 61 counties in the State of Maranhão, Brazil, from 2000 to 2009. Sixty-one counties located along the main road and railway corridors were selected as the study sites: I - São Luis-Timon (construction started in 1895): 27 counties along roads 135 and 316 and the line of the Northeastern Railway Company; II - São LuisAçailândia (beginning of the 1980s): 20 counties along roads 135 and 222 and the line of the Carajás Railroad; and III Açailândia-Carolina (beginning of the 1980s): 14 counties along road 010 and the North-South Railroad (Figure 1).

The ACL data were obtained from the Ministry of Health of Brazil and the demographic data from the Brazilian Institute of Geography and Statistics (IBGE).

An initial descriptive analysis of ACL incidence was conducted. Bayesian spatiotemporal Poisson regression models were constructed using WinBUGS software ${ }^{10}$. The response variable, $y_{i t}$, was the number of ACL cases reported in county $i$ in year $t$ (for $i=1,2 \ldots, 61$ and $t=1,2 \ldots, 10$ ). We assumed that $y_{i t}$ followed a Poisson distribution with a mean of $e_{i t} \theta_{i t}$, where $e_{i t}$ is the number of cases expected in county $i$ at time $t$, and $\theta_{i t}$ is the area-specific risk rate in county $i$ at time $t$.

The number of expected cases, $e_{i t}$, between 2000 and 2009 for each ${ }_{2} 6$ county $\sum_{\sum_{i=1}} p_{i t}$ calculated with the equation $e_{i t}=p_{i} p_{t}, p_{t}={ }_{\mathrm{i}=1}{ }^{\mathrm{it}} / \sum_{\mathrm{i}=1} P_{i t}$, where $p_{i t}$ is the population in county $i$ at time $t$.

In the disease-mapping literature, estimates of $R R$ are obtained throughamaximum likelihood estimator, which, in this case, is given by $\theta_{i t}=y_{i t} / e_{i t}$ Estimates of $\theta_{i t}$ based on maximum likelihood estimators are biased, especially when the disease is rare, or the region of interest has a small population ${ }^{8}$.

In the present study, the spatiotemporal model considers $\log \left(\theta_{i t}\right)=\beta_{\mathrm{t}}+b_{i t,}$, where the temporal effect is given by $\beta_{t}=\beta_{t-1}$ $+w_{t}$, and $w_{t}$ is a normally distributed random error with a mean of zero and an unknown variance. This model assumes that the $\mathrm{RR}$ is related to both the temporal effect $\beta_{\mathrm{t}}$ and spatiotemporal effect $b_{i t}$.

Prior distributions must be specified for the model parameters. We modeled the random effects terms, $b_{i t}$, as a conditional auto-regressive (CAR) model with variance of $\sigma_{b}^{2}$. For $w_{t}$, we assumed an a priori non-informative Gaussian distribution with a mean of zero and an unknown variance of $\sigma_{w}^{2}$. Additional references using CAR prior distributions for disease mapping are provided by Bernardinelli et al. ${ }^{6,11,12}$. Inverse-gamma prior distributions were specified for all of the variance parameters, with a shape of $\mathrm{a}=1$ and a scale of $\mathrm{b}=1$.

We estimated the parameters through an MCMC simulation. Three parallel chains were run with different initial values for the parameter estimates. A burn-in of 5,000 interactions, followed by 10,000 interactions was allowed, and the values of the main parameters were stored. Terra View software, version 3.5, was used for mapping the resulting posterior distribution of the estimated RR parameters.

\section{Ethical considerations}

This study was approved by the Ethics Committee of the University Hospital of Maranhão Federal University (243/2008).

\section{RESULTS}

From 2000 to 2009 , there were 13,818 cases of ACL recorded, including 4,571 cases along Line I ( 169 cases/county), 7,137 cases (357 cases/county) along Line II and 2,110 cases (151 cases/county) along Line III.

The annual incidence of ACL is shown in Figure 2. Since 2000, a gradual decrease in ACL incidence has been reported in the studied areas. This pattern of occurrence was common to the three lines.

The RRs for each of the 61 counties during 2000-2009 are provided in Figure 3 and Table 1. The counties along Line II always presented a high risk. However, the eastern region (Line I) of the state showed a significant decrease in risk over the study years. Along Line III, different risks were observed in the counties.

Throughout the study period, the RR increased in $77 \%$ of counties, decreased in $18 \%$ and was maintained in only five counties.

\section{DIscussion}

Recent advances in techniques and computer-based programming have helped scientists and researchers monitor environmental and ecological factors affecting the spatial and temporal distribution of several vector-borne diseases, including malaria, leishmaniasis and schistosomiasis, among other diseases ${ }^{7-9,13}$

The Bayesian model employed here provided an estimate of the RR of ACL in the examined counties during the study period. The epidemiologic data indicated a significant decrease in the incidence of ACL over the ten years addressed in this study. The examined counties were situated in an historical area for ACL transmission and displayed incidences ranging from 7.36 to $241.45 / 100,000$ inhabitants ${ }^{14,15}$.

The area with the highest incidence of ACL was located in the western region of the state (Line II), which is under the influence of the Amazon rainforest and is known as an endemic disease area in Brazil ${ }^{14,15}$. The climate and vegetation of this forest favor a high diversity of vector species, reservoirs and etiological agents ${ }^{16-18}$. The phlebotomine fauna found in this area are quite diverse, with an abundance of $L$. whitmani, L. migonei, L. umbratilis and $L$. complexa being observed ${ }^{14,19,20}$.

The eastern region of the state (Line I) is also under the influence of the Amazon forest, combined with the transitional palm forest and Cerrado moving from west to east. These 


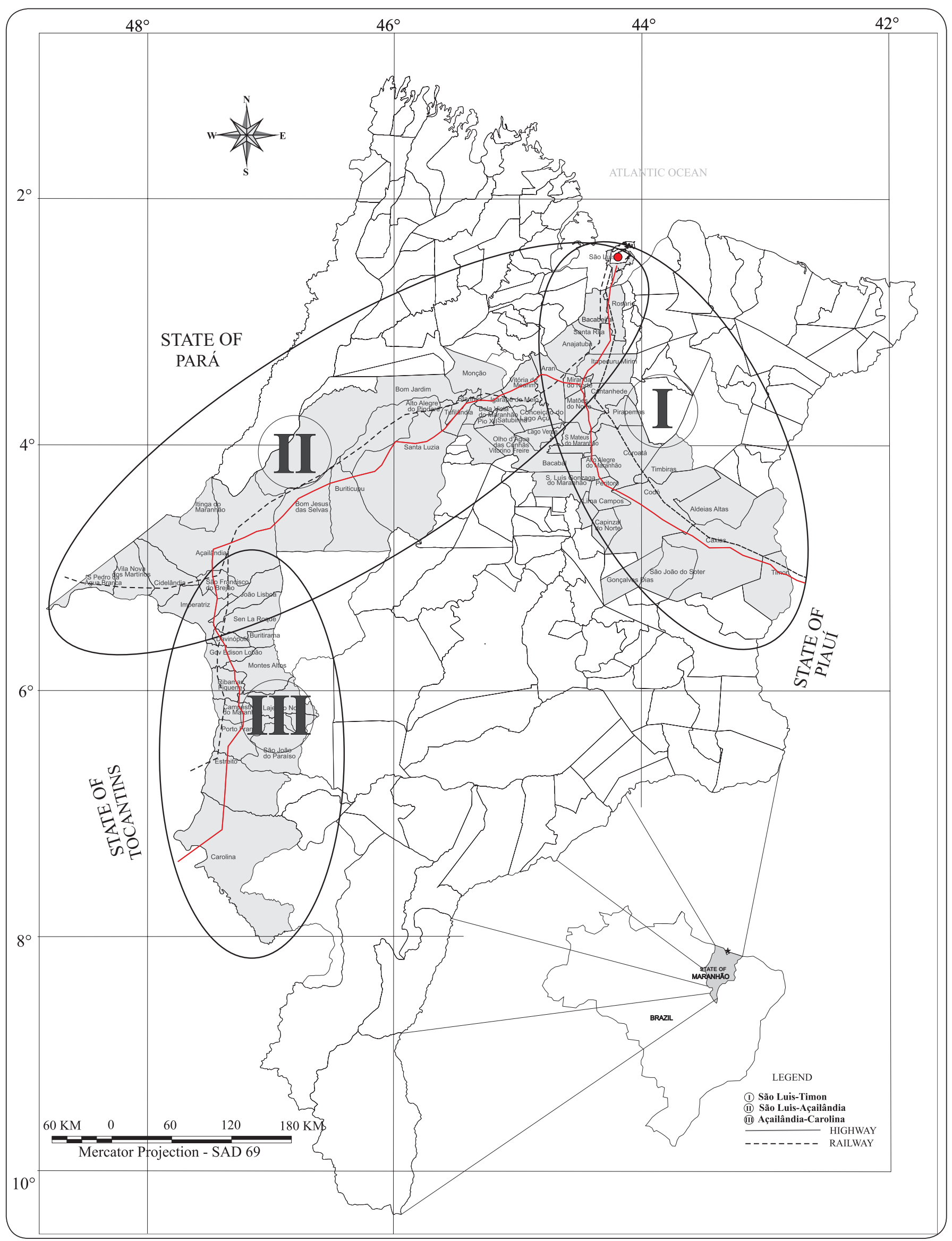

FIGURE 1 - Map of the State of Maranhão, Brazil, showing the studied counties located along the road and railway corridors, 2000-2009. 


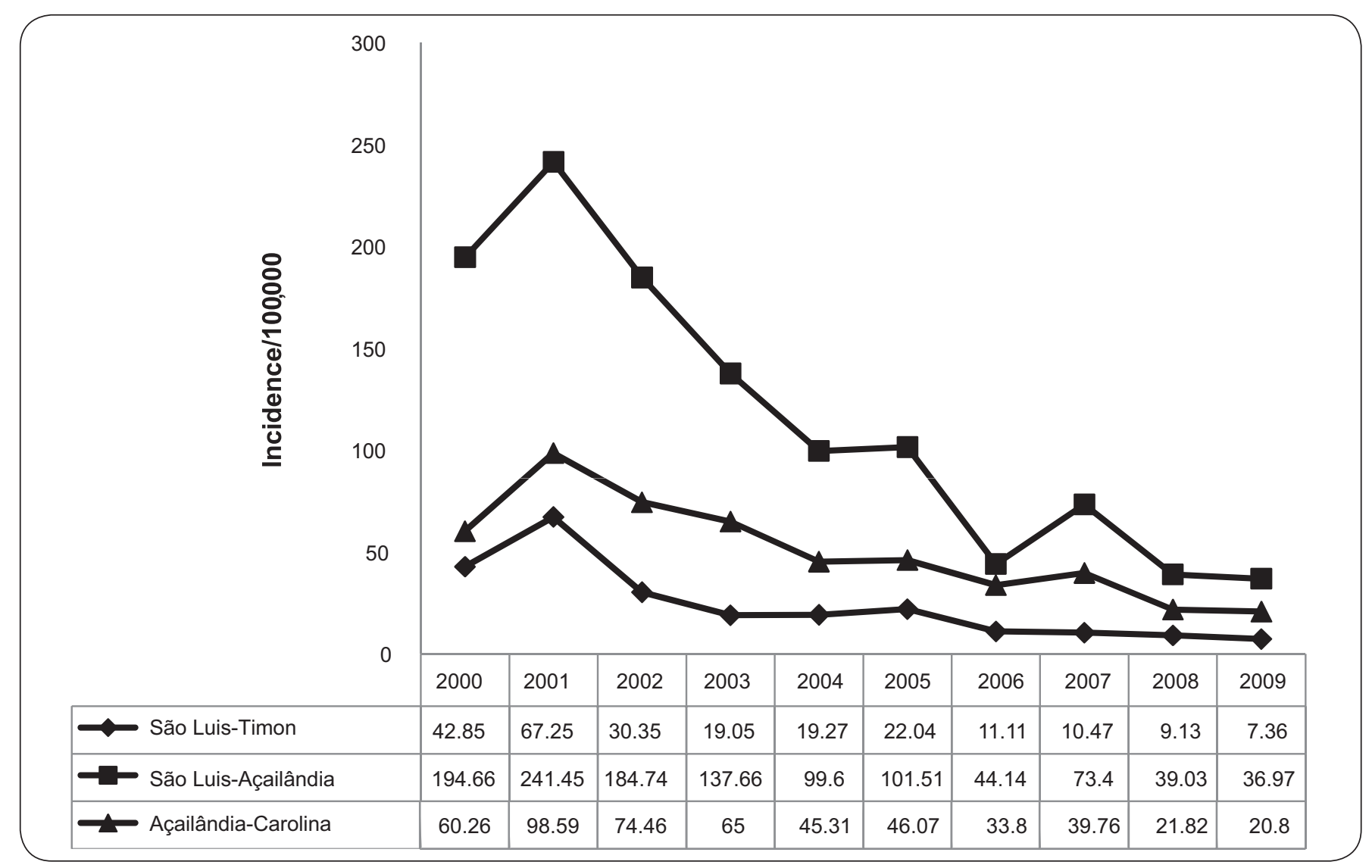

FIGURE 2 - Incidence of American cutaneous leishmaniasis cases along road and railway corridors in the State of Maranhão, Brazil, $2000-2009$.

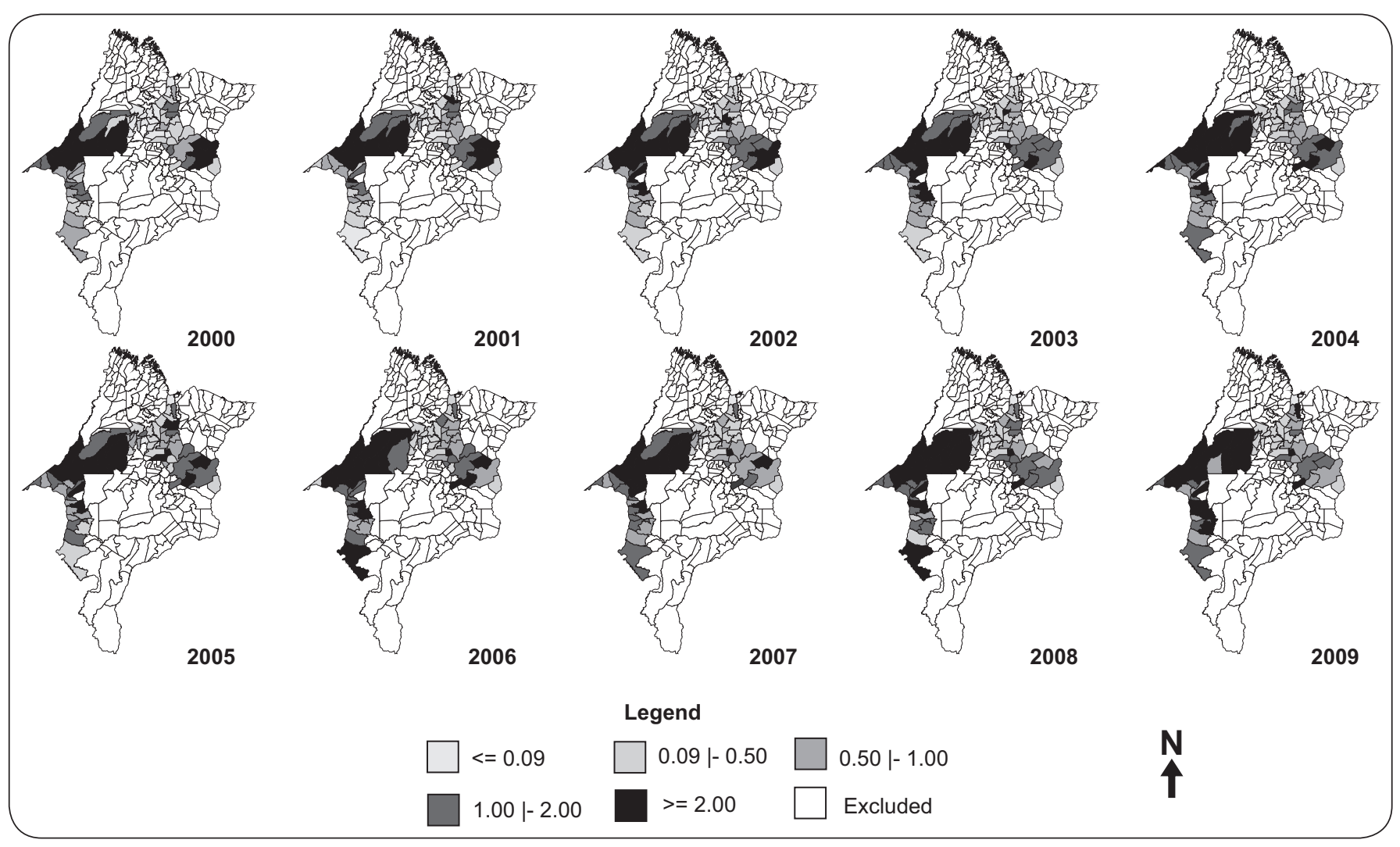

FIGURE 3 - The relative risk of American cutaneous leishmaniasis in the counties located along road and railway corridors in the State of Maranhão, Brazil, 2000-2009. 
TABLE 1 - Relative risk of American cutaneous leishmaniasis in the cities located along the road and railway corridors, State of Maranhão, Brazil, 2000-2009.

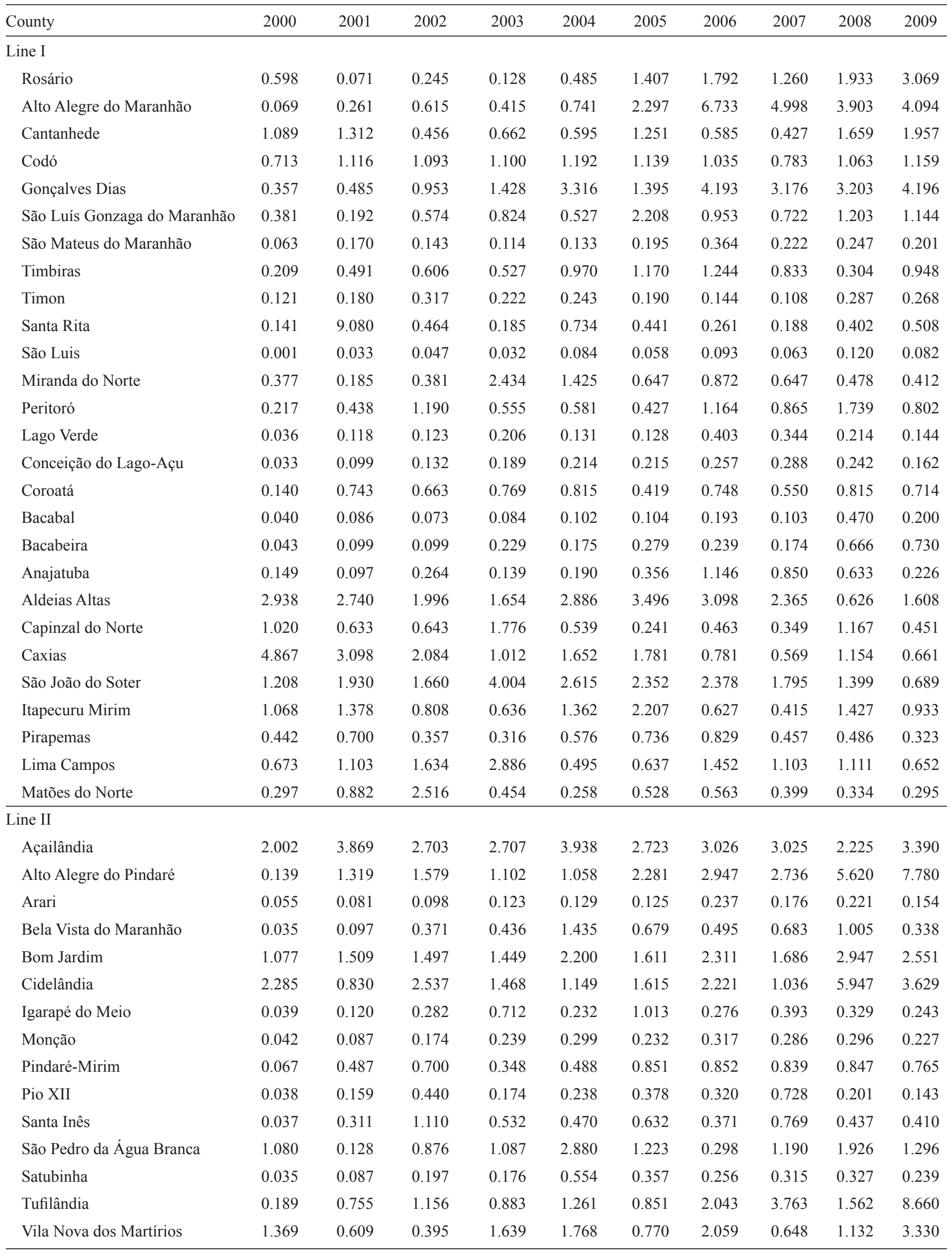


TABLE 1 - Continue.

\begin{tabular}{|c|c|c|c|c|c|c|c|c|c|c|}
\hline County & 2000 & 2001 & 2002 & 2003 & 2004 & 2005 & 2006 & 2007 & 2008 & 2009 \\
\hline Vitória do Mearim & 0.031 & 0.060 & 0.081 & 0.287 & 0.392 & 0.146 & 0.210 & 0.209 & 0.310 & 0.131 \\
\hline Bom Jesus das Selvas & 4.472 & 1.867 & 5.459 & 5.301 & 4.644 & 6.323 & 5.631 & 5.960 & 3.463 & 0.952 \\
\hline Buriticupu & 12.910 & 7.875 & 11.98 & 10.13 & 6.431 & 7.162 & 4.172 & 4.636 & 2.504 & 2.609 \\
\hline Itinga do Maranhão & 7.582 & 5.025 & 3.944 & 5.035 & 8.994 & 4.460 & 6.334 & 8.221 & 6.615 & 7.347 \\
\hline \multicolumn{11}{|l|}{ Line III } \\
\hline Campestre do Maranhão & 0.487 & 0.531 & 0.414 & 0.886 & 0.407 & 0.605 & 0.878 & 1.067 & 0.456 & 0.622 \\
\hline Carolina & 0.539 & 0.060 & 0.203 & 0.428 & 1.035 & 0.435 & 3.500 & 1.636 & 3.275 & 1.200 \\
\hline Davinópolis & 0.949 & 2.847 & 2.079 & 3.875 & 0.407 & 1.720 & 1.558 & 1.250 & 1.423 & 1.527 \\
\hline Lajeado Novo & 1.229 & 0.581 & 0.581 & 3.144 & 1.641 & 0.779 & 2.329 & 1.140 & 1.056 & 3.198 \\
\hline Montes Altos & 1.007 & 1.025 & 3.237 & 4.434 & 3.446 & 2.744 & 10.570 & 3.725 & 2.280 & 3.450 \\
\hline Porto Franco & 0.460 & 0.420 & 0.628 & 0.838 & 0.824 & 1.076 & 0.852 & 1.245 & 1.033 & 1.169 \\
\hline Ribamar Fiquene & 0.556 & 0.412 & 0.741 & 1.517 & 1.095 & 0.794 & 1.609 & 1.127 & 1.432 & 2.425 \\
\hline São João do Paraíso & 0.173 & 0.228 & 0.342 & 0.944 & 0.577 & 0.283 & 0.690 & 0.527 & 1.601 & 10.41 \\
\hline Senador La Rocque & 0.641 & 1.645 & 3.173 & 5.899 & 3.006 & 2.904 & 1.541 & 2.937 & 2.898 & 2.239 \\
\hline São Francisco do Brejão & 7.120 & 2.991 & 2.608 & 1.573 & 1.376 & 0.844 & 2.602 & 3.381 & 1.574 & 1.599 \\
\hline Estreito & 0.538 & 0.292 & 0.520 & 0.732 & 0.810 & 1.487 & 1.426 & 0.958 & 0.343 & 0.563 \\
\hline
\end{tabular}

Source: Secretary of Health Surveillance/Ministry of Health of Brazil.

characteristics may explain why the incidence found in this region is higher than that recorded in the southwest of the state, which is dominated by Cerrado formations, as the climate is drier in the south ${ }^{21,22}$.

Studies have shown that many species of phlebotomine ACL vectors previously found in wild environments ${ }^{19,20}$ are encroaching on rural and peri-urban areas, where they are becoming infected by Leishmania spp. ${ }^{17,23}$.

The first records of ACL in Maranhão come from the late 1970s from an outbreak detected in Buriticupu ${ }^{15}$ on the Amazon side of the state. A number of outbreaks recorded in Maranhão, São Paulo and Bahia were associated with the introduction of roads and railway lines in forest $\operatorname{areas}^{24,25}$, and we believe the same phenomenon may have occurred along road and railway Line I. However, this line is much older and has existed for more than a century with no record of an infection. Thus, it is possible that the lack of cases reported in association with this line resulted from the absence of disease specialists at the time.

This hypothesis finds support in current records of autochthonous cases of ACL in urban areas of $\mathrm{Caxias}^{26}$, which suggest a long-term adaptation process among phlebotomine sandflies (L. cortelezii, L. evandroi, L. goiana, L. intermedia, L. lenti, L. longipalpis, L. longipennis, L. squamiventris, L. termitophila, and L. whitmani) in these environments. This phenomenon was previously observed in an entomological survey conducted in several counties along this road and railway $\operatorname{line}^{27}$. However, such adaptation has not yet been detected on the Amazonian (west) side, where ACL remains rural or periurban $^{27,28}$.

Given the above findings, it is presumed that the studied road and railway lines have increasingly been drawing populations from Maranhão and other states from different regions in the country. The northwest road and railway line receives migrants from Pará, Tocantins and other Amazon states, whereas the northeast road and railway line mainly receives migrants from the States of Piauí and Ceará but also from other northeastern States and Minas Gerais. Thus, these lines facilitate the transmission of ACL in the oldest settled areas, such as the area along road and railway Line I receiving a large population flow from the northeastern states, as well as areas settled more recently, including along access routes to the Amazon states and the central region of Brazil.

In Brazil, health records are critical sources of data for studies. However, the availability and quality of the data are matters of great concern. For example, the lack of coverage of the entire population and diagnostic errors can affect the quality of the data and lead to underreporting. Reliability and validity are essential in large database studies to accurately assess the possibility of bias in spatial research based on secondary data ${ }^{29}$. 
Nevertheless, the results of this study can be interpreted despite their limitations and potential biases. First, the incidence rates of ACL are based on secondary data, which may underestimate the true incidence due to underreporting. A second potential problem was the failure to consider socioeconomic and environmental indicators given the difficulty of obtaining such data ${ }^{29}$.

To better understand the influence of roads on the epidemiological profile of this disease, further research will be required to identify variables that can contribute resolving the complex factors contributing to disease transmission.

Road and railway corridors may play an important role in the spread of LTA by facilitating the movement of populations with varying risks of contracting the disease, thus influencing its epidemiology.

The data presented and discussed in this report allow us to conclude that although there was a decrease in the incidence of ACL over the study period, the risk of contracting the disease remains in all of the studied municipalities. Therefore, preventive measures implemented by the Unified Health System should be directed towards the control of disease expansion.

\section{CONFLICT OF INTEREST}

The authors declare that there is no conflict of interest.

\section{REFERENCES}

1. Organización Mundial de la Salud (OMS). Lucha contra las leishmaniasis. Ginebra: OMS; 1990.

2. Ministério da Saúde. Secretaria de Vigilância em Saúde [Internet]. Casos de Leishmaniose Tegumentar Americana. Brasil, Grandes Regiões e Unidades Federadas. 1990 a 2010. Brasília: MS/SVS [Cited 2011 March 23]. Available from: http://portal.saude.gov.br/portal/arquivos/pdf/lta_casos08_09_11.pdf

3. Instituto Brasileiro de Geografia e Estatística (IBGE). Atlas do Maranhão. Rio de Janeiro: IBGE; 1984.

4. Assunção RM, Reis I.A, Oliveira CDL. Diffusion and prediction of Leishmaniasis in a large metropolitan area in Brazil with a Bayesian space-time model. Stat Med 2001; 20:2319-2335.

5. Prado RR, Castilho EA. The aids epidemic in the State of São Paulo: application of the full Bayesian space-time model. Rev Soc Bras Med Trop 2009; 42:537-542.

6. Bernardinelli L, Clayton D, Montomoli C. Bayesian Estimates of Disease Maps: how important are priors? Stat Med 1995; 14:2411-2431.

7. Choi J, Lawson AB, Cai B, Hossain M. Evaluation of Bayesian spatiotemporal latent models in small area health data. Environm 2011; 22:1008-1022.

8. Nobre AA, Schmidt AM, Lopes HF. Spatiotemporal models for mapping the incidence of malaria in Para. Environm 2005; 16:291-304.

9. Kato SK, Vieira DM, Fachel JMG. Utilization of fully Bayesian modeling to detect patterns in relative risk variation for infant mortality in Rio Grande do Sul State, Brazil. Cad Saúde Pública 2009; 25:1501-1510.

10. Spieglhalter DJ, Best NG, Carlin BP, Linde A. Bayesian measures of model complexity and fit. J Royal Stat Soc B 2002; 64:583-639.

11. Best NG, Arnold RA, Thomas A, Waller LA, Conlon EM. Bayesian models for spatially correlated disease and exposure data. In: Bernardo JM, Dawid JO, Berger AP, Smith AFM. Bayesian Statistics 6. Oxford Univ. Press 1999; p. 131-156.
12. Ketsall J, Wakefield J. Modeling Spatial Variation in Disease Risk: a Geostatistical Approach. J Am Statist Ass 2002; 97:692-701.

13. Elmaiem DE, Schorscher J, Bendall A, Obsomer V, Osman ME, Mekkaawi $\mathrm{AM}$, et al. Risk mapping of visceral leishmaniasis: the role of local variation in rainfall and altitude on the presence and incidence of kala-azar in eastern Sudan. Am J Trop Med Hyg 2003; 68:10-17.

14. Costa JML, Rebêlo JMM, Saldanha ACR, Balby IT, Gama MEA, Bezerril ACR, et al. Epidemiology of American Tegumentary Leishmaniasis (ATL) and perspectives of control in Maranhão, Brazil. Rev Hospital Universitário/UFMA 2005; 6:32-38.

15. Silva AR, Martins G, Melo JEM, Araújo JP, Mendes MG. Surto epidêmico de leishmaniose tegumentar americana na colonização agrícola de Buriticupu (MA), Brasil. Rev Inst Med Trop São Paulo 1979; 21: 45-50.

16. Oliveira-Pereira YN, Moraes JLP, Lorosa ES, Rebêlo JMM. Feeding preference of sandflies in the Amazon, Maranhão State, Brazil. Cad Saúde Pública 2008; 24:2183-2186.

17. Fonteles RS, Vasconcelos GC, Azevêdo PCB, Lopes GN, Moraes JLP, Lorosa ES, et al. Blood feeding preference of Lutzomyia whitmani (Diptera, Psychodidae) in an area of transmission of American cutaneous leishmaniasis in the State of Maranhão, Brazil. Rev Soc Bras Med Trop 2009; 42:647-650.

18. Rebêlo JMM, Rocha RV, Moraes JLP, Alves GA, Leonardo FS. Distribution of Lutzomyia whitmani in phytoregions of the state of Maranhão, Northeastern Brazil. Rev Saúde Pública 2009; 43:1070-1074.

19. Rebêlo JMM, Oliveira ST, Barros VLL, Silva FS, Costa JML, Ferreira LA, et al. Sandflies (Diptera: Psychodidae) of Lagoas, municipal district of Buriticupu, Amazonia of Maranhão. I - Richness and relative abundance of the species in area of recent colonization. Rev Soc Bras Med Trop 2000; 33:11-19.

20. Rebêlo JMM, Oliveira ST, Barros VLL, Silva FS. Phlebothominae of Amazon of Maranhão IV - Richness and relative abundance of species in an area of ancient settlement. Entomol \& Vec 2000; 7:61-72.

21. Instituto Brasileiro de Geografia e Estatística (IBGE) [Internet]. Cartografia. Rio de Janeiro: IBGE; 2010. [Cited 2010 July 5]. Available from: http://www.ibge.gov.br/home/geociencias/cartografia/default_geog int.shtm? $\mathrm{c}=6$.

22. Rebêlo JMM, Rocha RV, Moraes JLP, Silva CRM, Leonardo FS, Alves GA. The fauna of phlebotomines (Diptera, Psychodidae) in different phytogeographic regions of the state of Maranhão, Brazil. Rev Bras Entomol 2010; 54:494-500.

23. Oliveira-Pereira YN, Rebêlo JMM, Moraes JLP, Pereira SRF. Molecular diagnosis of the natural infection rate due to Leishmania sp in sandflies (Psychodidae, Lutzomyia) in the Amazon region of Maranhão, Brazil. Rev Soc Bras Med Trop 2006; 39:540-543.

24. Costa JML. Estudo clínico-epidemiológico de um surto epidêmico de leishmaniose tegumentar americana em Corte de Pedra, Bahia. [Masters Thesis]. [Brasília]: Universidade Nacional de Brasília; 1986.

25. Marzochi KBF, Marzochi MCA, Silva AF, Grativol N, Duarte R, Confort EM, et al. Phase 1 Study of an Inactivated Vaccine against American Tegumentary Leishmaniasis in Normal Volunteers in Brazil. Mem Inst Osw Cruz 1998; 93:205-212.

26. Silva MH, Nascimento MDSB, Leonardo FS, Rebêlo JMM, Pereira SRF. Genetic Differentiation in Natural Populations of Lutzomyia longipalpis (Lutz \& Neiva) (Diptera: Psychodidae) with Different Phenotypic Spot Patterns on tergites in Males. Neotrop Entomol 2011; 40:501-506.

27. Rebêlo JMM, Leonardo FL, Costa JML, Pereira YNO, Silva FS. Phlebothominae (Diptera, Psychodidae) of an endemic area of leishmaniasis in the region of cerrados, State of Maranhão, Brazil. Cad Saude Publica 1999; 15:623-630.

28. Costa JML, Saldanha ACR, Melo E, Silva AC, Serra-Neto A, Galvão CES, et al. Estado atual da leishmaniose cutânea difusa (LCD) no Maranhão. Rev Soc Bras Med Trop 1992; 25:115-123.

29. Randremanana RV, Richard V, Rakotomanana F, Sabatier P, Bicout DJ. Bayesian mapping of pulmonary tuberculosis in Antananarivo, Madagascar. BMC Infect Dis 2010; 10:21. 